\title{
PERUBAHAN TEKANAN DARAH SEBAGAI RESPON TERHADAP AKTIVITAS FISIK: FUTSAL PADA PRIA DEWASA MUDA PEROKOK DAN NON PEROKOK
}

\author{
Yunus Elon \\ Fakultas Ilmu Keperawatan, Universitas Advent Indonesia
}

Email: yunus.elon@unai.edu

\begin{abstract}
Background: Physical activity is the best way to maintain one's health. One of the physical activities that are currently popular among young people both smokers and non-smokers is futsal. This study aimed to determine changes in blood pressure that occur in smokers and non-smokers after playing futsal. Method: This study used quasi-experimental methods with pre-test and post-test design. The total sample of the study was 40 people who were evenly distributed in the two groups according to the criteria. Blood pressure was measured using a digital sphygmomanometer before and after playing futsal. Results: The average blood pressure of smokers before the futsal was 113,95/77,20 mmHg and the non-smoker group was 115,15 / 78,45 mmHg, which was interpreted as normal blood pressure. After playing futsal, the average blood pressure of smokers was 132,4 / 81.7 and the non-smoker group was 130,05 / 81,10 $\mathrm{mmHg}$. Paired t-test analysis showed significant differences in systolic and diastolic pressure before and after playing futsal in the group of smoker p-value <.05. In the non-smoker group, there were significant differences in systolic blood pressure $p$-value $<.05$, but not the diastolic p value $>.05$. Independent t-test showed significant differences in the systolic blood pressure in smokers and non-smokers after playing futsal p-value <.05. Conclusion: Although smoking habits accompanied by physical activity will still affect a person's health status, especially heart and blood vessel problems.
\end{abstract}

Keywords: Smoker, Futsal, Blood Pressure.

\begin{abstract}
Abstrak
Latar belakang : Aktifitas fisik adalah cara yang terbaik untuk mempertahankan kesehatan tubuh seseorang. Salah satu aktifitas fisik yang saat ini popular dikalangan anak muda baik perokok maupun non perokok yaitu futsal. Penelitian ini bertujuan untuk mengetahui perubahan tekanan darah yang terjadi pada perokok dan non perokok setelah bermain futsal. Metode : Penelitian ini menggunakan metode eksperimen semu (quasi experiment) dengan pre-test and pos-test design. Total sampel penelitian berjumlah 40 orang yang didistribusikan secara merata pada kedua kelompok sesuai dengan kriteria. Tekanan darah diukur menggunakan sphygmomanometer digital sebelum dan sesudah bermain futsal.

Hasil : Rata-rata tekanan darah kelompok perokok sebelum futsal adalah 113,95/77,20 $\mathrm{mmHg}$ dan kelompok non perokok 115,15/78,45 $\mathrm{mmHg}$, yang diinterpretasikan sebagai tekanan darah normal. Sesudah bermain futsal rata-rata tekanan darah kelompok perokok menjadi 132,4/81,7 dan kelompok non perokok 130,05/81,10 $\mathrm{mmHg}$. Analisis paired t-test memperlihatkan perbedaan signifikan pada tekanan systolik maupun diastolik sebelum dan sesudah bermain futsal pada kelompok perokok $p$ value <.05. Pada kelompok non perokok terdapat perbedaan signifikan pada tekanan darah sistolik $p$ value <.05, namun tidak pada diastolik $\mathrm{p}$ value $>.05$. Independent $t$-test memperlihatkan perbedaan signifikan pada tekanan darah sistolik kelompok perokok dan non perokok sesudah bermain futsal $p$ value <.05. Kesimpulan : Kebiasaan merokok walaupun disertai dengan aktifitas fisik akan tetap berpengaruh terhadap status kesehatan seseorang khususnya masalah jantung dan pembuluh darah.
\end{abstract}

Kata kunci: Perokok, Futsal, Tekanan Darah. 


\section{Pendahuluan}

Merokok merupakan salah satu kebiasaaan buruk yang terjadi diberbagai belahan dunia ini, dimana jumlahnya setiap tahun mengalami peningkatan. Drope dan Schhuluger (2018) dalam the Tobacco Atlas mencatat bahwa angka perokok didunia sangat tinggi. Sebanyak 942 juta laki-laki dan 175 juta perempuan, usia diatas 15 tahun adalah perokok. Selanjutnya disebutkan bahwa merokok berhubungan dengan penyakit jantung dan paru-paru. Data yang di rilis oleh, World Health Organozation (2019) menyatakan, bahwa tembakau membunuh hampir setengah penggunannya. Setiap tahun terdapat 7 juta orang yang meninggal sebagai akibat langsung tembakau, dan sekitar 1,2 juta karena perokok pasif. Dan yang sangat memprihatinkan adalah, sekitar $80 \%$ perokok didunia berasal dari negara dengan pendapatan rendah sampai menengah. Menurut WHO (2011) indonesia masuk kedalam kategori negara dengan pendapatan menengah.

Menurut Pusat Data dan Informasi Kementrian Kesehatan RI (2015) di ASEAN Indonesia menjadi negara dengan persentase konsumsi tembakau terbanyak yaitu sebanyak 46,16\%, diikuti oleh Filipina $(16,61 \%)$, dan Vietnam (14,11\%). Kementrian Kesehatan RI (Kemenkes RI, 2013) menyatakan bahwa jumlah perokok di Indonesia diperkirakan telah mencapai 65 juta jiwa dengan $40 \%$ diantaranya berasal dari kalangan ekonomi bawah. Yang lebih memprihantinkan lagi yaitu jumlah perokok pada generasi muda dan remaja terus mengalami peningkatan. Riskesdas (2018) memperlihatkan data, perokok usia 10-18 tahun mencapai $9.1 \%$. atau naik $0,3 \%$ dari tahun 2016. Hasil tersebut sejalan dengan penelitian yang dilakukan oleh, Elon dan Malinti (2019) dimana 40\% perokok berusia 14 tahun, 30\% 15 tahun, 20\% 16 tahun serta $10 \%$ berusiah 13 tahun.
Ariesyanto dan Untari (2011) menyatakan bahwa jika ditinjau dari segi kesehatan, rokok tidak mempunyai nilai dan manfaat bagi tubuh manusia dan dapat memengaruhi tekanan darah. Beberapa penelitian yang telah dilakukan menunjukkan bahwa kebiasaan merokok, jumlah rokok yang dikonsumsi perhari, lama merokok dan jenis rokok memiliki hubungan yang signifikan dengan tekanan darah tinggi atau hipertensi (Setyanda, Sulastri \& Lestari 2015; Fhoka, Trisnawati \& Pradana, 2015).

Salah satu cara untuk mengontrol ataupun mencegah tekanan darah tinggi adalah dengan meningkatkan aktifitas fisik termasuk rutin berolahraga. Hal inilah yang menjadi salah satu alasan bahwa pada usia muda individu terhindar dari tekanan darah tinggi oleh karena orang muda adalah orang-orang yang aktif. Namun demikian, merokok meningkatkan resiko hipertensi dan serangan jantung pada orang muda, sehingga dianjurkan untuk berhenti merokok (Yandrapalli, et al, 2019; \& Williamson, et al, 2019).

Aktifitas aerobik seperti berenang, bersepeda dan lari menambah beban pada sistem kardiovaskular sehingga meningkatkan tekanan darah. Peningkatan tekanan darah setelah olahraga adalah normal karena otot membutuhkan oksigen yang lebih (Vandergriendt, 2018; Weber, 2019). Olahraga yang banyak disukai oleh orang muda khususnya laki-laki adalah bermain futsal. Sumtari, Supriatna, dan Syukri, (2013) dalam laporannya menyatakan bahwa permainan futsal memiliki pengaruh terhadap Volume Oksigen Maksimum individu sehingga mengakibatkan perubahan nilai denyut nadi pada awal dan akhir permainan.

Sari (2013) menjelaskan bahwa olahraga futsal merupakan jenis aktivits fisik berat, sehingga saat melakukan permainan futsal, tekanan darah dapat meningkat cukup banyak disebabkan aktivasi saraf simpatis dan menyebabkan kontraksi pembuluh darah. 
Penelitian ini dilakukan untuk menilai perbedaan peningkatan tekanan darah yang terjadi pada pemain futsal perok dan nonperokok.

\section{Metode}

Desain yang digunakan dalam penelitian ini adalah kuantitatif dengan metode eksperimen semu (quasi experiment) menggunakan model pre-test and pos-test. Dengan membandingkan pretest dan posttest kedua kelompok. Sampel dalam penelitian ini dibagi menjadi dua, yaitu 20 orang perokok dan 20 orang non perokok yang dipilih dengan memakai teknik Non-Probabilitas model purposive sampling berdasarkan kriteria sebagai berikut:

Perokok adalah responden yang merokok dengan durasi 2-3 tahun, dengan jumlah konsumsi rokok 7-10 batang per hari. Non perokok adalah responden yang tidak pernah merokok sebelumnya. Kriteria secara umum responden adalah rutin bermain futsal selama $2 \mathrm{x}$ seminggu, memiliki tekanan darah sistolik $<120 \mathrm{mmHg}$ dan diastolik $<80 \mathrm{mmHg}$, usia 17-25 tahun dan secara sukarela menandatangani informed consent. Untuk memastikan tekanan darah responden berada dalam batas yang normal, peneliti melakukan pengukuran tekanan darah sebanyak 2 kali dengan selang satu hari, yang dilakukan pada jam yang sama.

Instrument yang digunakan yaitu Sphygmomanometer Digital yang telah dikalibrasi, alat tulis. Pengukuran tekanan darah dilakukan sebagai berikut.

(1) Responden diminta untuk beristirahat sejenak selama \pm 5 menit saat pertama kali datang ke lapangan futsal kemudian tekanan darah diukur dengan menggunakan sphygmomanometer digital. Hasil tekanan darah dituliskan pada lembar observasi.

(2) Responden diberikan waktu selama 20 menit untuk bermain futsal pada pertandingan pertama. Setelah itu, responden diminta untuk beristirahat selama 10 menit sesuai dengan peraturan yang berlaku.

(3) Responden melanjutkan pertandingan kedua permainan futsal selama 20 menit. Setelah itu, tekanan darah responden diukur kembali.

(4) Perolehan data dicatat pada lembaran catatan yang telah disiapkan oleh peneliti.

(5) Jumlah cairan yang diberikan pada setiap pemain dalam penelitian ini dibatasi hingga \pm 240 cc.

Perbedaan tekanan darah sebelum dan sesudah bermain futsal antar dua kelompok dihitung rata-ratanya. Perolehan nilai tekanan darah dibandingkan dengan klasifikasi tekanan darah menurut (American Heart Association, 2017):

\section{Tabel 1. Klasifikasi tekanan darah}

\begin{tabular}{lcc}
\hline \multicolumn{1}{c}{ Kategori } & $\begin{array}{c}\text { Tekanan } \\
\text { Sistolik } \\
(\mathbf{m m H g})\end{array}$ & $\begin{array}{c}\text { Tekanan } \\
\text { Diastolik } \\
(\mathbf{m m H g})\end{array}$ \\
\hline Normal & $<120$ & $<80$ \\
Elevasi & $120-129$ & $<80$ \\
Hipertensi Tahap 1 & $130-139$ & $80-89$ \\
Hipertensi Tahap 2 & $\geq 140$ & $\geq 90$ \\
Hipertensi Krisis & $\geq 180$ & $\geq 120$ \\
\hline
\end{tabular}

Sumber: AHA 2017

Pengolahan data dilakukan dengan menggunakan aplikasi komputer SPSS (Statistical Package for the Social Sciences). Paired sample t-test digunakan untuk mengetahui perbedaan tekanan darah perokok dan non perokok sebelum dan sesudah bermain futsal. Analisa perbedaan tekanan darah setelah futsal di antara kedua kelompok menggunakan independent $t$-test.

\section{Hasil dan Pembahasan}

Hasil uji deskripsi tekanan darah perokok dan non perokok sebelum dan sesudah bermain futsal ditampilkan pada tabel 2 dan 3. Hasil uji t ditabel 4 dan 5 berikut ini: 
Tabel 2: Uji Deskripsi tekanan Darah Perokok dan Non Perokok Sebelum Bermain futsal

\begin{tabular}{cccccc}
\hline Variabel & N & Min & Max & Mean & SD \\
\hline $\begin{array}{c}\text { Sistolik } \\
\text { Perokok }\end{array}$ & & 102 & 120 & 113.95 & 4.9 \\
$\begin{array}{c}\text { Diastolik } \\
\text { Perokok }\end{array}$ & & 56 & 90 & 77.20 & 8.7 \\
$\begin{array}{c}\text { Sistolik Non } \\
\quad \text { Perokok }\end{array}$ & & 100 & 120 & 115.15 & 5.8 \\
$\begin{array}{c}\text { Diastolik Non } \\
\quad \text { Perokok }\end{array}$ & 20 & 63 & 92 & 78.45 & 8.8 \\
\hline$S D=$ Standard deviation & & & &
\end{tabular}

Tabel 2 memperlihatkan rata-rata tekanan darah sistolik perokok sebelum bermain futsal adalah $113.95 \mathrm{mmHg}(\mathrm{SD}=4.9)$ dan diastolik sebesar $77.20 \mathrm{mmHg}(\mathrm{SD}=8.7)$ sementara Tekanan darah sistolik non perokok sebelum bermain futsal adalah $115.15 \mathrm{mmHg}(\mathrm{SD}=5.8)$ dan diastolik sebesar $78.45 \mathrm{mmHg}(\mathrm{SD}=8.8)$. Hasil pengukuran tekanan darah kedua kelompok masuk dalam kategori tekanan darah normal. American Heart Association (2018) menjelaskan tekanan darah sebagai tekanan yang diciptakan oleh aliran darah pada dinding pembuluh darah. Menurut AHA (2017) sesorang dikatakan memiliki tekanan darah normal jika tekanan sistolik $<120$ $\mathrm{mmHg}$ dan tekanan diastolik $<80 \mathrm{mmHg}$. Beberapa faktor yang dapat mempengaruhi tekanan darah antara lain; umur, jenis kelamin, olahraga, stres dan obesitas. Aktifitas fisik seperti olahraga yang dilakukan secara rutin dapat membantu dalam mempertahankan tekanan darah dalam keadaan normal (Beevers, Lip dan Oo'brien, 2014).

Table 3. Uji Deskripsi Tekanan Darah Perokok dan Non Perokok Sesudah Bermain futsal

\begin{tabular}{|c|c|c|c|c|c|}
\hline Variabel & $\mathrm{n}$ & Min & Max & Mean & SD \\
\hline Sistolik & & 127 & 138 & 132.4 & 3.6 \\
\hline Perokok & 20 & & & & \\
\hline $\begin{array}{l}\text { Diastolik } \\
\text { Perokok }\end{array}$ & & 74 & 90 & 81.7 & 5.1 \\
\hline $\begin{array}{l}\text { Sistolik Non } \\
\text { Perokok }\end{array}$ & & 126 & 134 & 130.05 & 2.2 \\
\hline $\begin{array}{l}\text { Diastolik Non } \\
\text { Perokok }\end{array}$ & 20 & 72 & 90 & 81.10 & 4.5 \\
\hline
\end{tabular}

Tabel 3 menunjukkan rata-rata tekanan darah sistolik perokok sesudah bermain futsal adalah $132.4 \mathrm{mmHg}(\mathrm{SD}=3.6)$ dan diastolik sebesar $81.7 \mathrm{mmHg}(\mathrm{SD}=5.1)$. Tekanan darah Sistolik non perokok sesudah bermain futsal adalah $130.05 \mathrm{mmHg}(\mathrm{SD}=2.2)$ dan diastolik sebesar $81.10 \mathrm{mmHg}(\mathrm{SD}=4.5)$. Tekanan darah kedua kelompok mengalami peningkatan. Latihan fisik dapat meningkatkan tekanan darah untuk sementara waktu. Hal ini merupakan hal alami yang disebut autoregulasi untuk pemenuhan kebutuhan otot. Kenaikan tekanan darah setelah aktifitas fisik tergantung pada seberapa berat aktifitas dan bagaimana kondisi kardiovaskular sesorang. Semakin sedikit peningkatan, semakin baik kondisi kesehatan seseorang (Weber, 2019).

Tabel 4. Analisis Perubahan Tekanan Darah Sebelum Dan Sesudah Bermain Futsal Non Perokok Dan Perokok

Variabel SD Std.EM Sig (2 tailed)

Sistolik Non Perokok

$\begin{array}{lll}4.71 & 1.05 & 0.00\end{array}$

Sebelum dan Sesudah

Diastolik Non Perokok

$8.56 \quad 1.91$

0.18

Sebelum dan Sesudah

Sistolik Perokok $3.95 \quad .88$

Sebelum dan Sesudah

Diastolik Perokok 8.89

1.98

0.03

Sebelum dan Sesudah

$P$ value $<.05, S D=$ Standard deviation, Std.EM=Standard error mean

Tabel 4 menunjukkan perubahan tekanan darah kedua kelompok sebelum dan sesudah bermain futsal. Terdapat perbedaan signifikan pada sistolik pada kelompok non perokok sebelum dan sesudah bermain futsal dengan $p$-value 0.00. Tidak ada perbedaan signifikan pada tekanan diastolik sebelum dan sesudah bermain futsal dengan $p$-value 0.182. Sedang pada kelompok Perokok terdapat perbedaan yang signifikan pada tekanan darah sistolik maupun diastolik sebelum dan sesudah futsal ( $p$-value <0.05). Vandergrientdt (2018) menjelaskan bahwa 
latihan fisik meningkatkan tekanan darah sistolik. Tekanan sistolik merupakan tekanan yang terjadi saat jantung berdenyut. Sedangkan tekanan diastolik adalah tekanan yang diukur diantara denyutan jantung, atau saat jantung relaks. Seharusnya tekanan darah diastolik tidak berubah secara siknifikan saat berolahraga. Peningkatan pada tekanan darah sistolik saat berolahraga merupakan usaha memompa darah untuk memenuhi kebutuhan yang meningkat saat beraktifitas. Sedangkan peningkatan signifikan pada tekanan darah diastolik saat aktifitas menunjukkan gangguan pada fungsi kardiovaskular (Oh, Hong, Lee, 2016).

Penelitian yang dilakukan oleh Jena dan Parohit (2016) menunjukkan bahwa perokok memiliki tekanan darah sistolik maupun diastolik lebih tinggi dibanding non perokok. Rokok mengandung bahan-bahan kimia yang berbahaya bagi fungsi kardiovaskular. Kandungan kimia dlam rokok meningkatkan stress oksidatif yang pada akhirnya menyebabkan inflamasi intravaskular, perkembangan atherosklerosis dan penyakit kardiovaskular (Papathanasiou, mamali, Papafloratos, \& Zerva, 2014).

Table 5. Analisis perbandingan tekanan Darah Perokok dan Non Perokok Sebelum dan Sesudah Bermain Futsal

\begin{tabular}{lccl}
\hline Variabel & n & MD & $\begin{array}{l}\text { Sig (2 } \\
\text { tailed) }\end{array}$ \\
\hline $\begin{array}{l}\text { Sistolik Perokok dan } \\
\text { Non Perokok Sebelum }\end{array}$ & 20 & 1.20 & 0.485 \\
$\begin{array}{l}\text { Futsal } \\
\text { Diastolik Perokok dan } \\
\text { Non Perokok Sebelum }\end{array}$ & 20 & 1.25 & 0.656 \\
$\begin{array}{l}\text { Futsal } \\
\text { Sistolik Perokok dan }\end{array}$ & & & \\
$\begin{array}{l}\text { Non Perokok sesudah } \\
\text { Futsal }\end{array}$ & 20 & 2.35 & $\mathbf{0 . 0 1 9}$ \\
$\begin{array}{l}\text { Diastolik Perokok dan } \\
\text { Non Perokok Sesudah }\end{array}$ & 20 & .600 & 0.697 \\
Futsal & & & \\
\hline *p value <.05, MD=Mean Differences & \\
\hline
\end{tabular}

Tabel 5 menunjukkan bahwa tekanan darah sistolik perokok dan non perokok sebelum bermain futsal memiliki mean difference 1.20 dengan nilai p sebesar 0.484 , sedangkan tekanan diastolik perokok dan non perokok sebelum bermain futsal memiliki mean difference sebesar 1.25 dengan nilai p 0.656 . Hal ini memberikan gambaran bahwa tidak ada perbedaan yang signifikan pada tekanan darah kedua group sebelum bermain futsal. Sedangkan tekanan darah sistolik perokok dan non perokok sesudah bermain futsal memiliki mean difference sebesar 2.35 dengan nilai $\mathrm{p} 0.019$, yang berarti terdapat perbedaan tekanan darah yang signifikan pada kedua kelompok sesudah bermain futsal dan tidak ada perbedaan signifikan pada tekanan diastolik kedua kelompok sesudah bermain futsal dengan nilai p sebesar 0.697.

Hasil penelitian ini didukung oleh Naldi, Y., dan Gani, I., (2013) bahwa terdapat perbedaan yang signifikan antara kelompok perokok dan non perokok sesudah bermain futsal. Dimana tekanan darah perorok meningkat lebih tinggi diabnding dengan non peokok. Andi, Afriwardi dan Iryani (2016), yang menemukan bahwa sesaat setelah bermain futsal tekanan darah sistolik akan meningkat hingga $20 \mathrm{mmHg}$ sedangkan tekanan darah diastolik tidak terlalu terpengaruh. Menurut Afriwandi, (2009) peningkatan tekanan darah pada saat aktifitas fisik merupakan kompensasi dari peningkatan kebutuhan oksigen dan nutrisi pada jaringan sehingga fungsi kardiovaskular meningkat untuk memenuhi kebutuhan oksigen serta mendistribusikan sisa metabolisme. Hoyt (2013) mengatakan, aktifitas fisik akan mengakibatkan peningkatan kebutuhan oksigen 20 kali lipat. Dimana oxygen dibutuhkan dalam proses pembentukan ATP oleh sel tubuh yang akan digunakan oleh otot untuk aktifitas fisik. Semakin tinggi intensitas aktifitas, maka semakin tinggi pula kebutuhan oksigen untuk metabolisme energi, sehingga membutuhkan tekanan lebih untuk memenuhi kebutuhan otot. Olahraga futsal merupakan jenis aktifitas fisik berat yang melibatkan kerja saraf simpatis. 
Bermain futsal dapat menyebabkan kenaikan tekanan darah karena kerja saraf simpatis yang akan bekerja melalui kontraksi pembuluh darah. Energi yang dibutuhkan saat bermain futsal sangat besar sehingga tubuh akan berusaha meningkatkan aliran darah yang cepat guna mensuplai nutrisi ke sel dan otot yang berkontraksi (Sari, 2013). Kebiasaan merokok memberi efek negatif pada fungsi saraf otonom yang mengatur fungsi kardiovaskular (Taralov, Dimov, Terziyski, Ilchev, \& Kostianev, 2015).

\section{Simpulan dan Rekomendasi}

Tekanan darah perokok dan non perokok, sesudah bermain futsal, mengalami peningkatan yang siknifikan khususnya tekanan darah sistolik. Peningkatan tekanan darah diastolik yang siknifikan hanya dialami oleh kelompok perokok. Terdapat perbedaan siknifikan pada tekanan darah sistolik sesudah futsal antara kedua kelompok. Sesudah berolahraga normalnya tekanan darah akan kembali ke batas awal, sehingga perlu penelitian lebih lanjut untuk membandingkan waktu istirahat yang dibutuhkan kedua kelompok untuk mencapai tekanan darah batas awal. Penelitian lain juga bisa dilakukan dengan membandingkan jenis olahraga yang berbeda.

\section{Daftar Pustaka}

Afriwandi (2009). Ilmu kedokteran olahraga. Jakarta: EGC.

American Heart Association. (2017). Understanding Blood Pressure Reading. American Heart Association [ONLINE] Available at:http://www.heart.org/HEARTOR G/Conditions/HighBloodPressure/K now YourNumbers/UnderstandingBlood-Pressure-Readings/ $[02$ Januari 2018]

American Heart Association. (2018).
Understanding Blood Pressure Reading. American Heart Association. [ONLINE] Available at: https://www.heart.org/en/healthtopics/high-bloodpressure/understanding-bloodpressure-readings

Andi, A., Afriwardi, A., dan Iryani, D., (2016). Gambaran perubahan tekanan darah pasca olahraga futsal pada mahasiswa fakultas kedokteran universitas andalas. Jurnal kesehatan Andalas. ISSN:2301-7406 Vol 5, No 2. [ONLINE] Available at: http://jurnal.fk.unand.ac.id/index.ph $\mathrm{p} / \mathrm{jka} /$ article/view/515

Ariesyanto, E., dan Untari, I. (2011).

Hubungan antara Jumlah Konsumsi Batang Rokok dengan Tingkat Hipertensi. Surakarta: AKPER PKU Muhammadiyah

Surakarta.

[ONLINE] Available at: https://www.google.com/url?sa=t\&r $\mathrm{ct}=\mathrm{j} \& \mathrm{q}=\&$ esrc $=\mathrm{s} \&$ source $=$ web\& $\mathrm{cd}$ =1\&ved=2ahUKEwj3 gpq6u6njAh WT7XMBHcWgDP8QFjAAegQIA BAC\&url=https $\% 3 \mathrm{~A} \% 2 \mathrm{~F} \% 2 \mathrm{Fejour}$ nal.stikespku.ac.id\%2Findex.php\% 2Fmpp $\% 2$ Farticle $\% 2$ Fdownload $\% 2$ F13\%2F11\&usg=AOvVaw2zJyRR R9GZRozKGm_KnaYD

Beevers, D. G., Lip, G. Y. H., dan O'Brien, E. (2014). "ABF of Hypertension". Sixth Edition. United Kingdom: BMJ Publishing Group.

Drope J, \& Schluger N, w., (2018). The Tobacco Atlas. Atlanta: American Cancer Society and Vital Strategies. $6^{\text {th }} \quad$ edi. $\quad[$ ONLINE] https://tobaccoatlas.org/wpcontent/uploads/2018/03/TobaccoAt las_6thEdition_LoRes_Rev0318.pd $\mathrm{f}$ 
Elon, Y., \& Malinti, E., (2019).

Fenomena Merokok Pada Anak Usia Remaja: Studi Kualitatif. Klabat Jurnal of Nursing (KJN) Vol.1 No.1. Hal.78-87. Available online

at http://ejournal.unklab.ac.id/index.ph $\mathrm{p} / \mathrm{kjn}$

Fhoka, F., Trisnawati, E., dan Pradana,

T. D. (2015). Hubungan Kadar Nikotin Rokok dengan Tekanan Darah pada Mahasiswa. Pontianak: Fakultas Ilmu Kesehatan Universitas Muhammadiyah Pontianak.

Fuadah, M. (2011). Gambaran Faktor faktor yang Mempengaruhi Perilaku Merokok pada Mahasiswa Laki-laki Fakultas Teknik Universitas Negeri Jakarta. Jakarta: Universitas Indonesia

Hoyt, G.L., (2013) Cigarette smoking: nicotine, carbon monoxide, and the physiological effects on exercise responses. Sport Science Review. 2013;22(1-2):5 - 24.

Jena SK, Purohit KC. Smoking status and its effect on blood pressure: A study on medical students. CHRISMED J Health Res 2017;4:14-8

Kementrian Kesehatan. (2013). Laporan Nasional Riset Kesehatan Dasar (RISKESDAS) 2013. Badan Litbangkes, Depkes RI. Jakarta.

Kementrian kesehatan repulik Indonesia (2016). HTTS 2016: Suarakan kebenaran, jangan bunuh dirimu dengan candu rokok. shttp://www.depkes.go.id/article/pri nt/16060300002/htts-2016- suarakan-kebenaran-jangan-bunuhdirimu-dengan-candu-rokok.html

Naldi, Y., dan Gani, I. (2013).

Perbedaan Tekanan Darah pada Perokok dan Bukan Perokok setelah Futsal. Cirebon: Universitas Swadaya Gunung Jati Cirebon.

Oh, D-J., Hong, H. O., \& Lee, B. A. (2016). The effects of strenuous exeercise on resting heart rate, blood pressure, and maximal oxygen uptake. Journal of Exercise rehabilitation. 12 (1): 42-46

Papathanasiou, G., Mamali, A., Papafloratos, S., \& Zerva, E. (2014). Effects of smoking on cardiovascular function: the role of nicotine and carbon monoxide. Health Science journal, 8 (2): 274 288

Pusat Data dan Informasi Kementrian

Kesehatan RI. (2015). Perilaku Merokok Masyarakat Indonesia Berdasarkan Riskesdas 2007-2013. Pusat Data dan Informasi Kementrian Kesehatan RI.

Sari, N. N. I. (2013). Perbedaan Efek Multi Stage Fitness Test Siswa Perokok dengan Bukan Perokok terkain Perubahan Nilai Nadi dan VO2Max di MAN Buntet Pesantren.

Setyanda, Y. O., Sulastri, D., dan Lesrari, Y. (2015). Hubungan Merokok dengan Kejadian Hipertensi pada Laku-laku Usia 35-65 tahun di Kota Padang. Jurnal Kesehatan Andalas 2015; 4(2).

Sumtari, Y. A., Supriatna, E., Syukri, M., (2013). Pengaruh Permainan Futsal terhadap VO2Max Siswa di SMP. Jurnal Pendidikan dan 
pembelajaran. Vol 2, No 6 . Available at: http://jurnal.untan.ac.id/index.php/j pdpb/article/view/2156
Young adults with first myocardial infarction. Journal of the Americacn College of Cardiology. 73 (5). DOI: 10.1016/j.jacc.2018.10.084

Vandergriendt, C. (2018). How does exercise affect blood pressure? Available at: https://www.healthline.com/health/ blood-pressure-after-exercise

Weber, C. (2019). Should my blood pressure be $120 / 80$ even after exercise? Available at: https://www.verywellhealth.com/sh ould-my-blood-pressure-be-12080even-after-exercise-1764088

WHO (2019). Tobacco. Available at:

https://www.who.int/news-room/factsheets/detail/tobacco

World Health Organization, Regional office for South-East Asia (WHO, ROSEA), (2011) Cardiovascular Disease Fact Sheet I Department of Sustainable Development and Healthy Environments I September 2011

Widiansyah, M. (2014). Faktor-faktor Penyebab Perilaku Remaja Perokok di Desa Sidorejo Kabupaten Penajam Paser Utara. Journal Sosiologi, 2014, 2 (4): 1-12.

Williamson, W., Foster, C., Reid, H., Kelly, P., Lewandowski, A. J., Boardman, H., ,.. et al. (2016). Will exercise advise be sufficient for treatmen of young adults with prehypertension? A systematic review and meta-analysis. Hypertension. 68: 78-87.

Yandrapalli, S., Nabors, C., Goyal, A., Aronow, W.s., \& Frishman, W.H. (2019). Modifiable risk factors in 